\title{
LA-ICP-MS U-Pb geochronology on monazite: Geologic "date" and geologic event duration. Comment on the paper by H.-J. Massonne, European Journal of Mineralogy, DOI:10.1127/ejm/2016/0028-2575
}

\section{Ivan Zagorchev}

Geological Institute “Acad. Str. Dimitrov”, Bulgarian Academy of Sciences, Acad. G. Bonchev str., 1113 Sofia, Bulgaria; E-mail: iszagorchev@yahoo.com

\section{LA-ICP-MS U-Pb геохронология по монацит: геоложка ,дата““ и времетраене на геоложко събитие. Коментар върху статията на Х.-Й. Масон, European Journal of Mineralogy, DOI:10.1127/ejm/2016/0028-2575}

\author{
Иван Загорчев \\ Геологически институт „Акад. Стр. Димитров“, БАН, ул. „Акад. Г. Бончев“, бл. 24, 1113 София
}

\begin{abstract}
Резюме. Коментира се статия върху една единствена проба от метапелити, принадлежащи на Луковишката свита от ПиринПангеонската единица. Посочват се несъответствия на интерпретациите на автора спрямо установени от самия него факти, както и спрямо отдавна известна геоложка информация за същите скали и локалитет. Посочва се, че метаморфното събитие, свързано с формирането на изследвания монацит, е отговаряло на интервала приблизително 62-24 Ма, т.е. обхваща палеогенското издигане на единицата и внедряването на Спанчевския (около $57 \mathrm{Ma}$ ) и Тешовския (около 32 Ма) плутон. Претендираното високобарично метаморфно събитие няма място в този времеви интервал.
\end{abstract}

Ключови думи: метапелити, монацит, Луковишка свита, Пирин-Пангеонска единица.

\begin{abstract}
We comment here a paper that is entirely built on a single sample of metapelites belonging to the Lukovitsa Formation in the Pirin-Pangaion unit. Some discrepancies in the interpretations of the author in respect of the facts established by himself as well as to long-known geological information for the same rocks and locality are pointed at. We emphasize that the "monazite formation event" corresponds to the interval of ca. 62-24 Ma, i.e., to the whole time of Paleogene uplift of the unit and the intrusion and exhumation of the Spanchevo (ca. $57 \mathrm{Ma}$ ) and Teshovo (ca. $32 \mathrm{Ma}$ ) plutons. The pretended HP metamorphic event cannot be inscribed in this time span.
\end{abstract}

Keywords: metapelites, monazite, Lukovitsa Formation, Pirin-Pangaion unit.

The comments on the paper cited in the title are provoked by several interpretation errors that give a false idea about the metamorphic evolution of the Rhodopian metamorphic supercomplex and the geodynamics of the Pirin-Pangaion tectonic unit. The author of these comments participated in the field work, and served as Reviewer of the criticized paper, making the same comments in the two consecutive reviews. After publication of the paper, these critical notes have been submitted twice to the European Journal of Mineralogy and rejected although the erroneous conclusions of the criticized paper about a Tertiary age of the HP metamorphic event "are obvious to anyone", as the Anonymous Reviewer of the first version of this Comment submitted to the Journal has written. However, the regional geological implications of these conclusions made upon a single sample are deceptive, and fully justify a comment. Therefore, I submit the comments to the Review of the Bulgarian Geological Society as the most reliable tribune to the problems of Bulgarian geology.

(1) Both in the abstract and in the discussion and conclusion chapters of Massonne (2016), the metamorphic grade of the first (and principal) metamorphic event is described as "the garnet core 
represents a low-P granulite or high-T amphibolite stage". At the same time, the evolution of the garnet core and rims are described as "(1) the garnet core represents a low-P granulite or high- $\mathrm{T}$ amphibolite stage; (2) the mantle domain and the Si contents in phengite reflect peak-P conditions of $16 \mathrm{kbar}$ at $500{ }^{\circ} \mathrm{C}$ and a subsequent exhumation to conditions of $10 \mathrm{kbar}$ and $565^{\circ} \mathrm{C}$; (3) slight heating occurred at $6.5 \mathrm{kbar}$ to produce the garnet rim." Obviously, the assertion about a phase of low-P granulite or high-T amphibolite facies cannot be truthful as far as the maximum temperatures recorded and cited are much below $600{ }^{\circ} \mathrm{C}$, i.e., corresponded to low-T amphibolite facies.

(2) The single sample taken and analyzed for monazite dating comes from garnet- and andalusite-bearing metapelites of the Lukovitsa Formation (Fig. 1). The mineral composition consists of "quartz, plagioclase, garnet, phengite, biotite, andalusite, and accessory phases ( 2 vol.\%) are ilmenite, Fe-hydroxy-oxides, rutile, zircon, apatite, monazite, baryte, and Fe-sulphides" (Massonne, 2016). Obviously as shown many years ago for the same mineral composition, rock and location (Boyad-
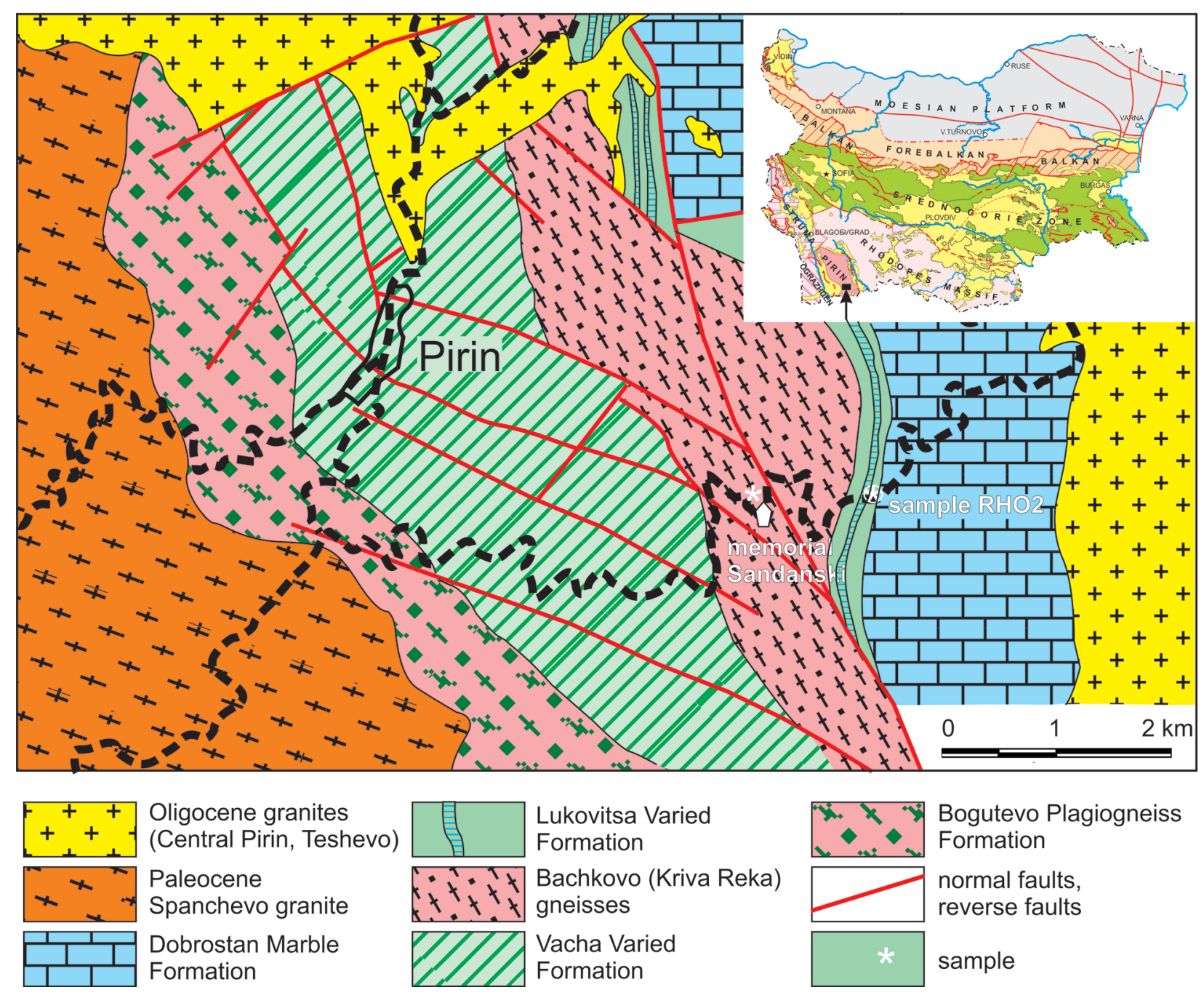

Bogutevo Plagiogneiss Formation

normal faults, reverse faults sample

Fig. 1. Simplified geological sketch map (after Zidarov et al., 1974 and Klimov et al., 2009) with the position of the Yane Sandanski Memorial (next - sample 309 with U-Pb zircon dating of the Bachkovo complex = Kriva Reka granite-gneisses) and of the sample RHO2 (Massonne, 2016) next to sample 310 (Zagorchev et al., 2017). Roads with broken thick line. Inset: Simplified tectonic map of Bulgaria (after Dabovski et al., 2002) with the position of the study area (black quadrangle pointed at with arrow).

Фиг. 1. Опростена геоложка скица (по Zidarov et al., 1974 и Klimov et al., 2009) с положението на паметника на Яне Сандански (в близост - на проба 309 с датировка по U-Pb цирконово датиране на Бачковския комплекс $=$ Криворечки гранитогнайси) и на проба RHO2 (Massonne, 2016) близо до проба 310 (Zagorchev et al., 2017). Пътищата са с плътна прекъсната линия. Във врезката: опростена тектонска карта на България (по Dabovski et al., 2002) с положението на изследвания район (черен правоъгълник, посочен със стрелка). 
jiev, 1959; Zidarov et al., 1974), these minerals are not in equilibrium, and belong to at least two different mineral parageneses. There is no petrologic evidence about monazite grains studied as belonging to the questionable HP metamorphic event nor about their intactness from later fluids and temperature increase due to the Paleogene intrusion of the Teshovo granite with the related andalusite-bearing paragenesis, skarns, etc. The age of the main event of the amphibolite facies metamorphism of the metapelites has been determined as late Variscan (mean date $300.8 \pm 1.8 \mathrm{Ma}$; possible event duration 310-295 Ma) by LA-ICP-MS studies on zircons (Zagorchev et al., 2017). This age is determined on a sample from a foliation-parallel quartzo-feldspathic gneiss within the metapelites taken at a few meters from the sample of Massonne. Samples from quartzo-feldspathic gneisses ("Kriva Reka metagranites", Bachkovo leptynites) taken near the Yane Sandanski Monument have also been determined with the same method as Variscan (Machev, Ovtcharova, 2008; Zagorchev et al., 2017).

(3) Although the monazite mineral dates are presented on his figures 8 and 9 (Massonne, 2016) the analytical information is not available, and it is not possible to understand whether all data points are concordant or not. However, it is clear (Fig. 2) that the monazite mineral dates cover continuously the whole interval between ca. 62 and $24 \mathrm{Ma}$, and this is also valid for each of the 3 populations distinguished after their different yttrium contents. The small differences in the mean mineral dates for the three populations are meaningless as all values within the three population fields overlap even on the $1 \sigma$ level.

There are two possible hypotheses, which follow from the existing field and petrological evidence. According to the first hypothesis the whole interval of monazite mineral dates (between ca. 62 and $24 \mathrm{Ma}$ ) is regarded as monazite event duration (Fig. 2). Monazite had been continuously formed in that time span, and it might be referred to a continuous mineral-forming event that corresponded to a geologic exhumation event coinciding with the formation of the Paleogene granitoids and the crystallization of andalusite. Stübner et al. (2015) determine the possible end of exhumation of the Teshovo granite at about $28 \mathrm{Ma}$, which is situated near the end of the monazite event duration.

The second hypothesis regards the monazite date interval as "mixed dates" due to the heating at the time of intrusion of the Teshovo granite and its con-

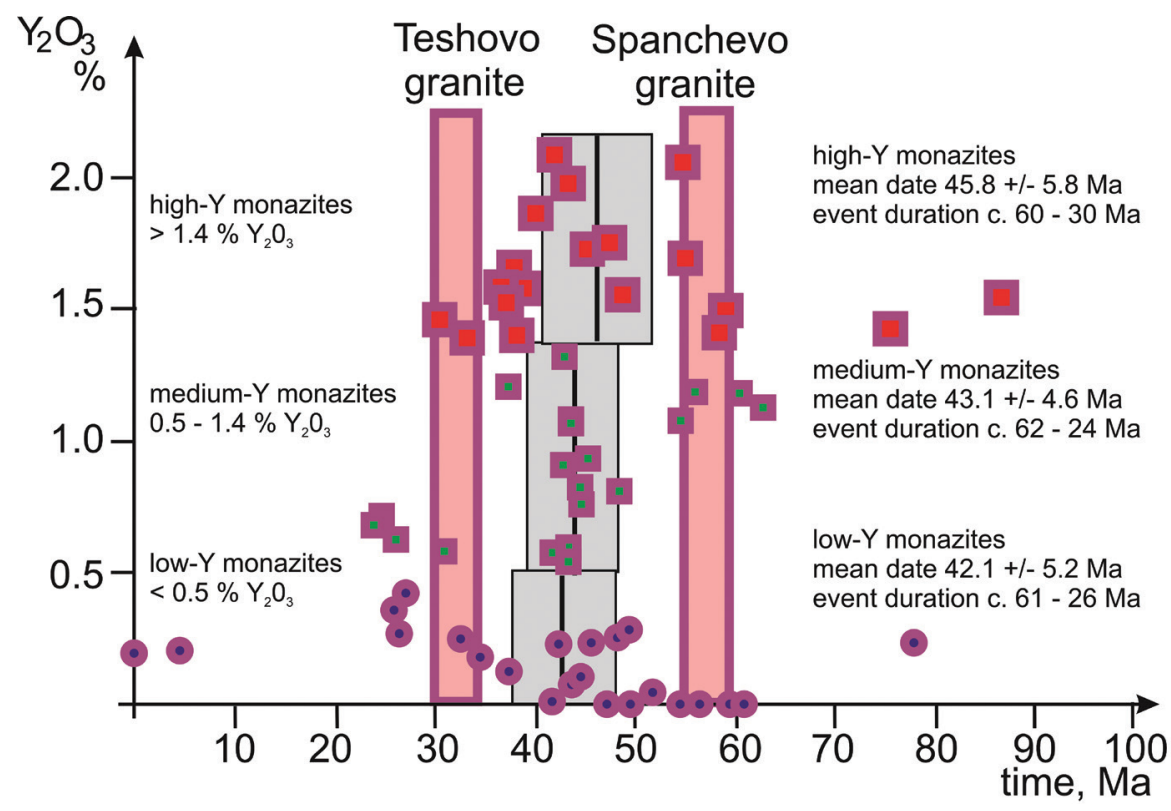

Fig. 2. Diagram for the monazite dates (Massonne, 2016, Figs 8 and 9) and the zircon dates (Machev et al., 2000; JahnAwe, 2010; Marchev et al., 2013; Zagorchev et al., 2017) for the intrusion of the Spanchevo and Teshevo granitoid plutons. Statistical means for the three monazite populations are shown with solid black lines, the area between the confidence limits in gray.

Фиг. 2. Диаграма за монацитните датировки (Massonne, 2016, Figs 8 and 9) и цирконовите дати (Machev et al., 2000; Jahn-Awe, 2010; Marchev et al., 2013; Zagorchev et al., 2017) на внедряването на Спанчевския и Тешевския гранитен плутон. Статистическите средни за трите монацитови популации са показани с пльтни черни линии, а площите между съответните доверителни граници са в сиво. 
sequent exhumation, and the related disturbance of the U-Pb system of the (possibly much) older monazite grains. The disturbance of monazite "dates" and the fluid-assisted crystallization of new monazite are a known phenomenon in the Rhodopes (Bosse et al., 2009, 2010; Didier et al., 2014), and have been reported in many other regions.

The suggested geochemical and geological scenario (Massonne, 2016) is not consistent with either of the hypotheses and with the known complex evidence about the evolution of the Pirin-Pangaion unit (Boyadjiev, 1959; Zidarov et al., 1974; Zagorčev, 1994; Zagorchev et al., 2017) and the whole Rhodopes (e.g., Liati, 2005; Bauer et al., 2007; Bosse et al., 2010; Didier et al., 2014, and many others), and could not be regarded as reliable. The time of the HP metamorphic event described is obviously older than the Paleogene exhumation of the unit, and is probably related to a Variscan or Cimmerian HP event. HP metamorphic events of such ages have been already reported from different parts of the Rhodopes (Wawrzenitz et al., 2015; Petrik et al., 2016). The monazite event duration corresponds en- tirely to the Paleogene exhumation of middle (?) and upper crust (the Pirin metamorphics) with decompression and granite formation and intrusion. As already known (Jahn-Awe et al., 2010; Zagorchev et al., 2014, 2017; references therein), the intrusion of the Spanchevo pluton is referred to the time span between ca. 58 and $55 \mathrm{Ma}$, and that of the Teshovo pluton, around 33-32 Ma.

It is also obvious that the use of mean (average) mineral dates for a given mineral and/or metamorphic event gives a false idea about the real geologic events and their duration. This practice could be compared to characterizing, e.g., the Paleogene Period by a "mean" or "average" age of ca. 44 Ma. Therefore, in similar cases a reference to the whole time span of concordant mineral ages should be made together with the calculated mean date and its confidence limits. The monazite data from the single metapelite sample RHO-2 (Massonne, 2016) points at a monazite-forming event duration of about 35 million years that is similar to a number of cases of prolonged metamorphic events reported in the literature.

\section{References}

Bauer, C., D. Rubatto, K. Krenn, A. Proyer, G. Hoinkes. 2007. A zircon study from the Rhodope metamorphic complex, N-Greece: Time record of a multistage evolution. - Lithos, 99, 207-228.

Bosse, V., P. Boulvais, P. Gautier, M. Tiepolo, G. Ruffet, J. L. Devidal, Z. Cherneva, I. Gerdjikov, J. L. Paquette. 2009. Fluid-induced disturbance of the monazite $\mathrm{Th}-\mathrm{Pb}$ chronometer: in situ dating and element mapping in pegmatites from the Rhodope (Greece, Bulgaria). - Chem. Geol., 261, 286-302.

Bosse, V., Z. Cherneva, P. Gautier, I. Gerdjikov. 2010. Two partial melting events as recorded by the U-Th-Pb chronometer in monazite: LA-ICPMS in situ dating in metapelites from the Bulgarian Central Rhodopes. - Geologica Balc., 39, 19th Congress of the Carpathian-Balkan Geological Association, Thessaloniki, Greece, 51-52.

Boyadjiev, S. 1959. On the geology of Pirin Mountain. - Ann. Direct. Rech. Géol. et Min., 8, 89-125 (in Bulgarian).

Dabovski, C., I. Boyanov, Kh. Khrischev, T. Nikolov, I. Sapounov, Y. Yanev, I. Zagorchev. 2002. Structure and Alpine evolution of Bulgaria. - Geologica Balc., 32, 2-4, 9-15.

Didier, A., V. Bosse, Z. Cherneva, P. Gautier, M. Georgieva, J. L. Paquette, I. Gerdjikov. 2014. Syn-deformation fluid-assisted growth of monazite during renewed high-grade metamorphism in metapelites of the Central Rhodope (Bulgaria, Greece). - Chem. Geol., 381, 206-222.

Jahn-Awe, S., N. Froitzheim, T. J. Nagel, D. Frei, N. Georgiev, J. Pleuger. 2010. Structural and geochronological evidence for Paleogene thrusting in the western Rhodopes, SW Bulgaria: Elements for a new tectonic model of the Rhodope Metamorphic Province. - Tectonics, 29, 3; DOI:10.1029/2009TC002558.
Klimov, I., R. Marinova, A. Marinova, I. Petrov, V. Valev. 2009. Geological Map of the Republic of Bulgaria in Scale 1:50 000, K-34-96-A (Gotse Delchev) Map Sheet. Sofia, Ministry of Environment and Water, Bulgarian National Geological Survey, Apis 50 Ltd.

Liati, A. 2005. Identification of repeated Alpine (ultra) highpressure metamorphic events by U-Pb SHRIMP geochronology and REE geochemistry of zircon: the Rhodope Zone of Northern Greece. - Contrib. Mineral. and Petrol., 150, 608-630.

Machev, Ph., M. Ovcharova. 2008. Metamorphosed Hercynian granites from Western Pirin Mountain. - In: Sofia University "St Kliment Ohridski", 60 Years Subject Geology, $115-121$.

Machev, Ph., I. Peytcheva, Y. Kostitsyn, G. Rashkova. 2000. Magma mingling and mixing in the Teshovo granitoid pluton (South Pirin Mountain, Bulgaria). II. Isotope-geochemical evidence. - Ann. Univ. de Sofia, Fac. géol. et géogr., 93, 1-géol., 163-172.

Marchev, P., S. Georgiev, R. Raicheva, I. Peytcheva, A. von Quadt, M. Ovtcharova, N. Bonev. 2013. Adakitic magmatism in post-collisional setting: An example from the Early-Middle Eocene Magmatic Belt in Southern Bulgaria and Northern Greece. - Lithos, 180-181, 159-180.

Massonne, H.-J. 2016. A Tertiary high-pressure metamorphism recorded in andalusite-bearing micaschist, southern Pirin Mts., SW Bulgaria. - Europ. J. Mineral., 28, 1187-1202; DOI:10.1127/ejm/2016/0028-2575.

Petrik, I., M. Janak, N. Froitzheim, N. Georgiev, K. Yoshida, V. Sasinkov, A. P. Konečny, S. Milovska. 2016. Triassic to Early Jurassic (c. $200 \mathrm{Ma}$ ) UHP metamorphism in the Central Rhodopes: evidence from U-Pb-Th dating of monazite 
in diamond-bearing gneiss from Chepelare (Bulgaria). $-J$. Metamorph. Geol., 34, 265-291.

Stübner, K., K. Drost, R. Schoenberg, M. Böhme, J. Starke, T. A. Ehlers. 2015. Asynchronous timing of extension and basin formation in the South Rhodope core complex, SW Bulgaria, and northern Greece. - Tectonics, 35; DOI: $10.1002 / 2015$ TC004044.

Wawrzenitz, N., A. Krohe, I. Baziotis, E. Mposkos, A. R. C. Kylander-Clark, R. L. Romer. 2015. LASS U-Th-Pb monazite and rutile geochronology of felsic high-pressure granulites (Rhodope, N Greece): Effects of fluid, deformation and metamorphic reactions in local subsystems. - Lithos, 232, 266-285.

Zagorčev, I. 1994. Structure and tectonic evolution of the PirinPangaion Structural Zone (Rhodope Massif, southern Bulgaria and northern Greece). - Geol. J., 29, 241-268.
Zagorchev, I., C. Balica, E. Kozhoukharova, I. Balintoni, G. Sabau, E. Negulescu. 2014. Palaeogene igneous evolution of the Rhodopes. - In: Proceedings of the National Conference with International Paricipation "Geosciences 2014". Sofia, Bulg. Geol. Soc., 35-36.

Zagorchev, I., C. Balica, E. Kozhoukharova, I. C. Balintoni. 2017. Pirin metamorphic and igneous evolution revisited in a geochronological frame based on U-Pb zircon studies. Geologica Balc., 46, 1, 27-63.

Zidarov, N., I. Zagorčev, I. Slavov, Y. Shabatov, S. Nedyalkova, V. Toprakchieva, L. Katseva, Y. Vodencharov, Y. Gercheva, A. Simeonov. 1974. Notes on the metamorphic rocks in Pirin. - Jb. Ministerum der Schwerindustrie. Staatliche Wirtschaftsverband "Geologische Forschungen”, 20 (1971), 262-278 (in Bulgarian with English abstract).

Постьпила на 11.09.2020 г., приета за печат на 25.09.2020 г. Отговорен редактор Йоио Янев 